\title{
Risk Assessment on Irrigation of Vitis vinifera L. Cv Malbec with $\mathrm{Hg}$ Contaminated Waters
}

\author{
Adrián Spisso, ${ }^{\ddagger}$ Pablo H. Pacheco, ${ }^{\dagger}$ Federico J. V. Gómez, ${ }^{\dagger}$ M. Fernanda Silva, ${ }^{\dagger}$ and Luis D. Martinez ${ }^{\ddagger} * *$ \\ ${ }^{\dagger}$ Instituto de Biología Agrícola de Mendoza (IBAM-CONICET), Alte.Brown 500, Chacras de Coria, CP 5505 Mendoza, Argentina \\ ${ }^{\star}$ Instituto de Química de San Luis (INQUISAL-CONICET), Chacabuco y Pedernera, CP 5700 San Luis, Argentina
}

\section{Supporting Information}

\begin{abstract}
Concerns regard watering crops with $\mathrm{Hg}$ contaminated waters have arisen worldwide recently. In these sense $\mathrm{Hg}$ uptake by Vitis vinifera L. cv. Malbec was evaluated under greenhouse conditions by the administration of $\mathrm{Hg}^{2+}$ for 4 days through irrigation water (short-term administration). Vines uptake $\mathrm{Hg}$ translocating it from roots through stems to leaves. Roots accumulated the higher $\mathrm{Hg}$ concentration. $\mathrm{Hg}$ in stems and leaves was accumulated mostly as organic $\mathrm{Hg}$, bind to different moieties. Size exclusion chromatography (SEC) and ion pair chromatography (IPC) were employed to reach insights into these ligands. $\mathrm{Hg}$ is distributed mainly in high molecular weight fractions of $669 \mathrm{kDa}$ in vine plants. In stems and leaves, $\mathrm{Hg}-\mathrm{S}$ associations were found in 669 and $66 \mathrm{kDa}$

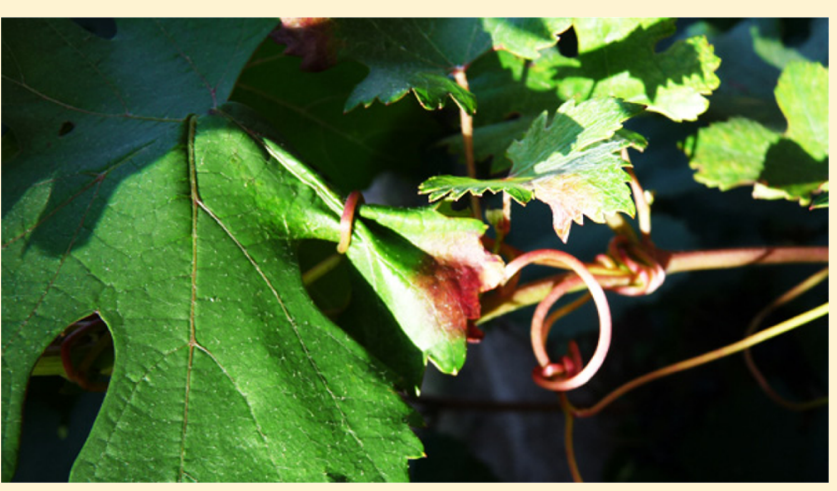
fractions. $\mathrm{Hg}-\mathrm{S}$ association at $66 \mathrm{kDa}$ suggests a possible protein or peptide binding affecting vines normal physiology. Since $\mathrm{Hg}$ contamination through organomercurials is more harmful than $\mathrm{Hg}^{2+}$ itself, methyl mercury, dimethyl mercury, and phenyl mercury, more toxic $\mathrm{Hg}$ species were evaluated with negative results.
\end{abstract}

\section{INTRODUCTION}

Mercury has an average crustal abundance on Earth of approximately $0.05-0.10 \mathrm{mg} \mathrm{kg}$, the majority of which occurs at the mineral cinnabar. ${ }^{1}$ Natural sources and transport mechanisms include volcanic emissions, wind borne dust, geysers, thermal fluids, and sea-spray. ${ }^{1,2} \mathrm{Hg}$ has been extensively used in the production of electrical goods, pulp and paper products, paints, dental applications, and pesticide formulations. About half of the anthropogenic input to the environment, including irrigation channels, has come from the manufacturing of caustic soda and chlorine by the electrolysis of brine. ${ }^{3}$ Volatility of some $\mathrm{Hg}$ species has turned this metal into a global pollutant which has been measured in the deep ocean, the atmosphere, Antarctica and the Arctic. ${ }^{1}$

Even in the absence of direct exposure, toxic elements represent a hazard to human population, because the food chain connects the elements of soil and air with humans. Uptake and accumulation by plants represents the main entry pathway for potentially health-threatening toxic metals into human and animal food. The exposure to $\mathrm{Hg}$ both directly and through the food chain is of significant concern and has resulted on more than one occasion in remedial response activation in regions of the U.S. and in other parts of the world. $^{4,5}$

It has been documented that plants absorb elements which have no known biological function and are even known to be toxic at low concentrations. Among these are $\mathrm{As}, \mathrm{Cd}, \mathrm{Cr}, \mathrm{Hg}$, and $\mathrm{Pb}$. However, even micronutrients become toxic for plants when absorbed above certain threshold values. Metal-ion contamination is a serious type of pollution in the environment. For plants, it can induce development problems such as growth decrease, reduced biomass production, and other morphological and biochemical alterations. ${ }^{6,7}$ Plants uptake essential and nonessential elements from soils in response to concentration gradients induced by selective uptake of ions by roots, or by diffusion of elements in soil. ${ }^{8}$ Bioavailability refers to the ability of an element to be transferred from the soil to a living organism. ${ }^{9}$ Evaluating bioavailability should provide information regarding risks of contaminant transfer and accumulation into the food chain. ${ }^{9-12}$

Viticulture represents an important agricultural practice in many countries. ${ }^{13}$ Metals in wine define its origin, and more important, its quality. They contribute to the formation of opacity and to the color, aroma and taste of wines. The final content is therefore the result of a number of different variables, such as the chemical and physical characteristics of the soil in which vines have grown. ${ }^{14}$ The irrigation water quality is another important variable defining the transportation of metals and other elements necessary for vine growth from soil toward the plant. ${ }^{15}$ Irrigation with contaminated waters can seriously increase the probability of toxic metals uptake into vine plants.

Received: November 20, 2012

Revised: April 15, 2013

Accepted: May 16, 2013

Published: May 16, 2013 
Irrigation channelss can be contaminated from different sources like industrial effluents, ${ }^{16}$ wastewaters, ${ }^{17}$ and geological processes. $^{18}$

The metal uptake capacity of Vitis vinifera has been reported elsewhere. ${ }^{19-21}$ Elevated heavy metal concentrations were found in xylem saps of vines showing a relatively high mobility within the plants. ${ }^{20}$ Chopin et al. ${ }^{19}$ studies showed differences between elements uptake resulted from vegetation uptake strategies and soil partitioning. In addition, it has been demonstrated that $\mathrm{Hg}$ content in vines cultivated in $\mathrm{Hg}$ contaminated soils is elevated compared with vines grown in soils with a normal $\mathrm{Hg}$ concentration. ${ }^{21}$

Despite the fact that many works have studied vines metal uptake from contaminated soils, little is known about the possibility of crops irrigation with $\mathrm{Hg}$ contaminated waters. The aim of this work is the assessment of $\mathrm{Hg}$ uptake and distribution by Vitis vinifera L. cv. Malbec through short-term $\mathrm{Hg}$ supplementation to vines cultivated in green house conditions. Studies of $\mathrm{Hg}$ biotransformation into different plant organs will be performed through the analysis of total $\mathrm{Hg}$, organic and inorganic fractions, and distribution according to molecular weight. $\mathrm{Hg}$ analysis was also expanded to the search of more toxic $\mathrm{Hg}$ substances like $\mathrm{MeHg}^{+}, \mathrm{Me}_{2} \mathrm{Hg}$ and $\mathrm{PhHg}^{+}$. Information about how vines, a major global crop, metabolize $\mathrm{Hg}$ after exposure has not been fully explored or understood.

\section{EXPERIMENTAL SECTION}

2.1. Procedures. 2.1.1. Plants Cultivation and Supplementation. Plants were obtained from Estación Experimental Agropecuaria Mendoza, Instituto Nacional de Tecnología Agropecuaria (INTA). The experiment was carried out at Facultad de Ciencias Agrarias, Universidad Nacional de Cuyo, Mendoza, Argentina $\left(33^{\circ} 0^{\prime} \mathrm{S}, 68^{\circ} 52^{\prime} \mathrm{W}\right)$ at an altitude of 940 $\mathrm{m}$. One-year-old plants of a selected clone of Vitis vinifera L. $c v$. Malbec were planted in $1.0 \mathrm{~L}$ plastic pots filled with $450 \mathrm{~g}$ of grape compost. Grape compost consists of three parts of pomace, two parts of loam, and two parts of perlite ( $\mathrm{pH}$ : 7.2; conductivity: $18.3 \mathrm{~m} \Omega \mathrm{cm}^{-1}$; organic matter $\left.9 \%\right)$. They were grown in a green house at temperatures ranging from 23 and 27 ${ }^{\circ} \mathrm{C}$ (night and day). In order to reproduce a situation where vines are irrigated with $\mathrm{Hg}$ contaminated water, the short-term supplementation procedure reported by Afton et al. ${ }^{22}$ was adapted with modifications. Plants were split into four groups of three plants each. Three groups were supplemented with $\mathrm{Hg}^{2+}$ (as $\mathrm{HgCl}_{2}$ ) at $25 \mathrm{~mL} \mathrm{~d}^{-1}$ for 4 days as depicted: $10 \mathrm{mg}$ $\mathrm{L}^{-1} ; 50 \mathrm{mg} \mathrm{L}^{-1} ; 100 \mathrm{mg} \mathrm{L}^{-1}$, and the rest one was employed as control and no $\mathrm{Hg}$ was added. Plants were allowed to mature for one additional week before sampling. The health of each plant was visually indifferent to the supplementation given. During the process of sampling, plants were separated into roots, stems, and leaves. They were immersed in an ultrasonic bath for a complete soil removal, washed with ultrapure water, and lyophilized. Fine roots were chosen for $\mathrm{Hg}$ uptake analysis as fine roots accumulated higher trace element concentrations; they would provide more accurate data on vegetation response to trace element presence in the environment and should, thus, be selected for bioavailability studies. ${ }^{19}$ Finally, the different plant organs were stored at $-5{ }^{\circ} \mathrm{C}$ to prevent any further enzymatic activity leading to interspecies conversion, therefore changing the native distribution. Soil samples were collected after $\mathrm{Hg}$ supplementation in order to determine the root bioavailable $\mathrm{Hg}$ concentration and the total $\mathrm{Hg}$ content. After collection, soil samples were lyophilized and stored at $-5{ }^{\circ} \mathrm{C}$ to prevent any further enzymatic activity.

2.1.2. Extraction Procedures. A mild extraction procedure of $\mathrm{Hg}$ from vine tissues was adapted from Meng et al. ${ }^{23}$ to reach extraction of free $\mathrm{Hg}$ and $\mathrm{Hg}$ bond to different ligands in the plant. $0.3-0.5 \mathrm{~g}$ of vine plants organs samples were digested using a mortar followed a $\mathrm{KOH}$-methanol/solvent extraction technique. In this process, vegetal organ samples were first digested with a $\mathrm{KOH}\left(5 \%, \mathrm{w} \mathrm{v}^{-1}\right)-\mathrm{CH}_{3} \mathrm{OH}\left(50 \%, \mathrm{v} \mathrm{v}^{-1}\right)$ solution and heated at $50{ }^{\circ} \mathrm{C}$ in a water bath for $3 \mathrm{~h}$. After completion, extracts were centrifuged at $3500 \mathrm{rpm}$ for five minutes. The supernatant was acidified with $\mathrm{HPO}_{3}$.

Soil samples were treated following the procedure reported by Cattani et al. $^{24}$ for the extraction of $\mathrm{Hg}$ bond to different ligands. One $\mathrm{g}$ of soil was mixed with $9 \mathrm{~mL} \mathrm{HCl}\left(7.6 \%, \mathrm{w} \mathrm{v}^{-1}\right)$ and $1 \mathrm{~mL}$ mercaptoethanol $\left(10 \%, \mathrm{v} \mathrm{v}^{-1}\right)$ in a polycarbonate bottle. The mixture was placed in an ultrasonic bath for $45 \mathrm{~min}$, with addition of ice to avoid an excessive warming of the bath water, and then centrifuged for $5 \mathrm{~min}$ at $3000 \mathrm{rpm}$. Following centrifugation the supernatant $\mathrm{pH}$ was adjust to 7.0 with ammonia $\left(10 \%, \mathrm{w} \mathrm{v}^{-1}\right)$. Finally, before analysis, both extracts, from vine and soil samples, were filtered through a $0.45 \mu \mathrm{m}$ membrane. Bioavailable $\mathrm{Hg}$ was determined by weighting $1 \mathrm{~g}$ of soil then shaken with $10 \mathrm{~mL}$ of $0.05 \mathrm{~mol} \mathrm{~L}^{-1}$ EDTA solution, $\mathrm{pH} 5.0$ for $2 \mathrm{~h}$ on a rotary shaker. After that the mixture was centrifuged (4000 rpm) and filtered prior analysis.

For the assessment of $\mathrm{Hg}$ distribution by size exclusion chromatography (SEC), an extraction stage involving liquid nitrogen and a mortar followed by the addition of $2 \mathrm{~mL}$ of a $2 \%$ $\left(\mathrm{w} \mathrm{v}^{-1}\right)$ SDS - $30 \mathrm{mM}$ Tris solution was performed. Extraction was completed after a $2 \mathrm{~h}$ ultrasonication bath and centrifugation at $5000 \mathrm{rpm}$ at $4{ }^{\circ} \mathrm{C}$. Supernatant was collected and filtered through $0.22 \mu \mathrm{m}$ filter prior injection for analysis. ${ }^{25}$

2.1.3. Microwave Assisted Digestion. The microwave digestion for total $\mathrm{Hg}$ determination in vine organs samples was performed as follows: $0.5 \mathrm{~g}$ were weighed and placed in individual microwave graduated polystyrene tubes. The aliquots were treated with $7 \mathrm{~mL}$ of $\mathrm{HNO}_{3} 65 \%\left(\mathrm{v} \mathrm{v}^{-1}\right)$ and $1 \mathrm{~mL}$ of $\mathrm{H}_{2} \mathrm{O}_{2}\left(3: 1, \mathrm{v} \mathrm{v}^{-1}\right)$. Dissolution was carried out at a ramp temperature of $10 \mathrm{~min}$ up to $200{ }^{\circ} \mathrm{C}$ and hold for 10 more minutes. The employed microwave power was up to $1000 \mathrm{~W}$.

2.1.4. Total Hg and Organic/Inorganic Fraction Determination. In order to reach organic $\mathrm{Hg}\left(\mathrm{Hg}_{\text {org }}\right), \mathrm{Hg}$ bond to different ligands; and inorganic $\mathrm{Hg}\left(\mathrm{Hg}_{\text {inorg }}\right), \mathrm{Hg}^{2+}$ or free, determination, a $100 \mu \mathrm{L}$ injection valve and rotary pumps were employed to propel the sample to an UV-CV-AFS system (Figure S1 of the Supporting Information (SI)). For determination of $\mathrm{Hg}_{\text {inorg }}\left(\right.$ as $\left.\mathrm{Hg}^{2+}\right), \mathrm{HCl} 30 \%\left(\mathrm{v} \mathrm{v}^{-1}\right)$, and $\mathrm{SnCl}_{2} 10 \%\left(\mathrm{~m} \mathrm{v}^{-1}\right)$ in $\mathrm{HCl} 30 \%\left(\mathrm{v} \mathrm{v}^{-1}\right)$ were introduced to the system. For $\mathrm{Hg}_{\text {org }}$ fraction determination, $\mathrm{K}_{2} \mathrm{~S}_{2} \mathrm{O}_{8} 1 \%\left(\mathrm{~m} \mathrm{v}^{-1}\right)$ in $30 \%\left(\mathrm{v} \mathrm{v}^{-1}\right) \mathrm{HCl}, \mathrm{NaBH}_{4} 0.5 \%\left(\mathrm{~m} \mathrm{v}^{-1}\right)$ in $0.5 \% \mathrm{NaOH}$ were introduced into the system under $\mathrm{UV}$ irradiation. $\mathrm{Hg}_{\text {or }}$ decomposition by this procedure has been assessed before. ${ }^{28}$ Under these conditions it has been stated that $\mathrm{Hg}_{\text {org }}$ in different concentrations values reach a decomposition range of 95.3$99.7 \% .^{26}$

Total $\mathrm{Hg}$ determinations were performed in the microwave assisted digests of root, leave, and stem samples. The employed technique was ICP MS. Two $\mathrm{mL}$ of the sample digests were introduced into the system. Determinations were carried out directly in the digests.

2.1.5. Ion Pair and Size Exclusion Chromatography. Determination of $\mathrm{MeHg}^{+}, \mathrm{Me}_{2} \mathrm{Hg}$, and $\mathrm{PhHg}^{+}$was performed 
by ion pair chromatography (IPC) coupled to UV-CV-AFS. Separation conditions were adapted from Cattani et al. ${ }^{25}$ with modifications. Operating conditions of the LC pump are summarized in Table S1 (SI). 2-Mercaptoethanol added in the mobile phase can be used as anion-pair reagent, forming complexes with $\mathrm{Hg}^{2+}, \mathrm{MeHg}^{+}$, and $\mathrm{PhHg}^{+}$in order to reach the separation of these compounds. Chemically, $\mathrm{Hg}^{2+}, \mathrm{MeHg}^{+}$, and $\mathrm{PhHg}^{+}$have extremely strong affinities for sulfhydryl-containing ligands. $^{24}$

The separation was achieved employing a gradient mode elution. First, a mobile phase (A) of $100 \%\left(\mathrm{v} \mathrm{v}^{-1}\right)$ buffer phosphate $\mathrm{pH}$ 7.0; 2-mercaptoethanol $0.1 \%\left(\mathrm{v} \mathrm{v}^{-1}\right)$ was introduced to reach the separation of $\mathrm{Hg}^{2+}$ and $\mathrm{MeHg}^{+}$. Once $\mathrm{Hg}^{2+}$ was eluted $(551 \mathrm{~s}$ ) the mobile phase was changed to $65 \%\left(\mathrm{v} \mathrm{v}^{-1}\right)$ buffer phosphate $\mathrm{pH} 7.0 ; 2$-mercaptoethanol $0.1 \%$ $\left(\mathrm{v} \mathrm{v}^{-1}\right)$ and $35 \%\left(\mathrm{v} \mathrm{v}^{-1}\right)$ methanol (B) to reach the elution and separation of $\mathrm{PhHg}^{+}$and $\mathrm{Me}_{2} \mathrm{Hg}$. B mobile phase was increased at a rate of $2.5 \% \mathrm{~min}^{-1}$ in order to change the strength of the gradient. AFS technique shows a great advantage in comparison with ICP MS because it can tolerate the introduction of solutions with a higher content of organic solvents such as methanol, like in this separation $\left[35 \%\left(\mathrm{v} \mathrm{v}^{-1}\right)\right]$, keeping comparable detection limits. Figure $4 a$ shows the optimized separation.

SEC was performed coupling the chromatographer to ICP MS. Buffer ammonium acetate $50 \mathrm{mM}$ was employed being adequate for coupling with ICP MS, since its volatility do not generate deposits on ICP cones. Bovine serum albumin (66 $\mathrm{kDa})$, Alcohol dehydrogenase $(150 \mathrm{kDa}), \beta$-amilase $(200 \mathrm{kDa})$, Thyroglobulin (669 kDa), and Apoferrtin (443 kDa) were employed for calibration.

2.2. Statistical Analysis. All samples were collected and analyzed in duplicate and the duplicate tests were statistically similar as paired-samples $t$ test $(p=0.05)$. The average results were used to represent the data. Microsoft Excel was used to test one-way analysis of variance (ANOVA) at 95\% confidence to investigate the effect of $\mathrm{Hg}$ concentration into irrigation water on $\mathrm{Hg}$ uptake capacity by vines.

The least significant difference (LSD) was calculated as follows:

$$
\mathrm{LSD}=\sqrt{\sigma_{0}^{2}} \times \sqrt{\frac{2}{n}} \times t_{\mathrm{h}(n-1)}
$$

\section{RESULTS AND DISCUSSION}

3.1. Total Hg Determinations. Total $\mathrm{Hg}$ determinations were performed in three aliquots of the whole plants after a total microwave assisted digestion. Determinations were made for the three supplementation groups and the control group. Results can be observed in Figure 1. Vines uptake $\mathrm{Hg}$ and transport it from roots to leaves. The maximum $\mathrm{Hg}$ concentration value was found for the group supplemented with $100 \mathrm{mg} \mathrm{L}^{-1}$ corresponding to $86.43 \pm 15.98 \mu \mathrm{g} \mathrm{g}^{-1}$, followed by group supplemented with 50 and $10 \mathrm{mg} \mathrm{L}^{-1}$ corresponding to $66.08 \pm 11.31$ and $29.06 \pm 3.56 \mu \mathrm{g} \mathrm{g}^{-1}$, respectively (for all determinations results are expressed as the mean \pm standard deviation of three plants). This fact is in agreement with previous studies where it was described a higher $\mathrm{Hg}$ uptake when vines where grown in $\mathrm{Hg}$ contaminated soils, ${ }^{21}$ however the elevated $\mathrm{Hg}$ concentrations are overwhelming considering the low time of exposure, only 4 days. This can be explained considering the high mobile nature of the

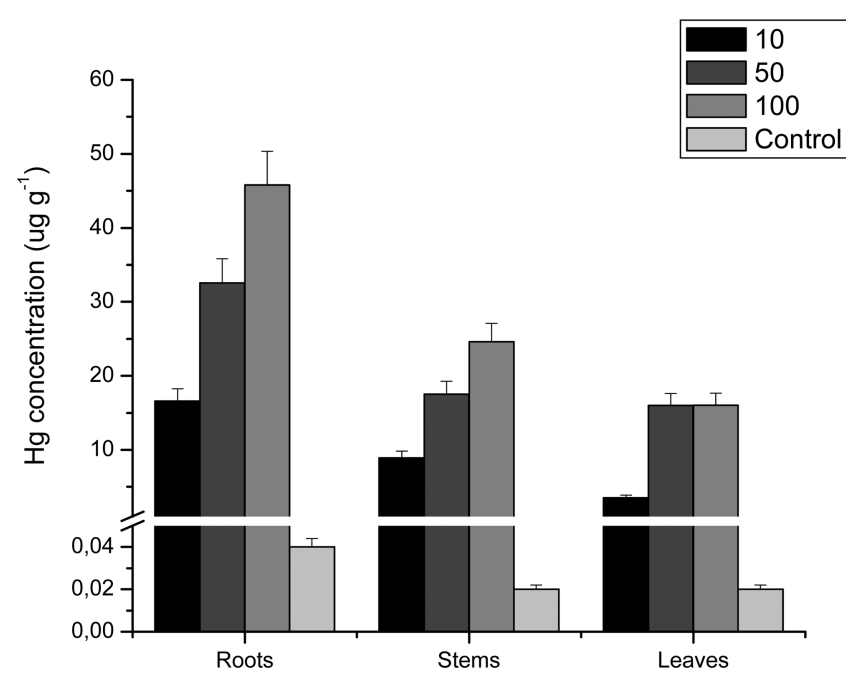

Figure 1. Total $\mathrm{Hg}$ concentration into the different vine compartments evaluated for 10,50 , and $100 \mathrm{mg} \mathrm{L}^{-1}$ of $\mathrm{Hg}^{2+}$ supplementation. Results are expressed as the mean \pm standard deviation of three plants.

$\mathrm{Hg}$ source, the irrigation water. Elevated $\mathrm{Hg}$ concentration values were found in roots, stems, and leaves compared with those grown in soil with lower $\mathrm{Hg}$ levels. The control group showed concentrations of $0.04 \pm 0.01,0.02 \pm 0.01$, and $0.02 \pm$ $0.01 \mu \mathrm{g} \mathrm{g}^{-1}$ for roots, stems, and leaves, respectively.

From the analysis of the aerial and nonaerial organs of the plant it can be observed that $\mathrm{Hg}$ concentrations in roots were of $16.61 \pm 2.34,32.57 \pm 4.3$, and $45.77 \pm 6.2 \mu \mathrm{g} \mathrm{g}^{-1}$, for groups supplemented with 10,50 , and $100 \mathrm{mg} \mathrm{L}^{-1}$, respectively. No significant difference was observed between groups supplemented with 10 and 50; and 50 and $100 \mathrm{mg} \mathrm{L}^{-1}(\mathrm{LSD}=17.58$ $\left.\mu \mathrm{g} \mathrm{g}^{-1}\right)$. A similar trend is advised in leaves, corresponding to $3.52 \pm 1.1,16.0 \pm 3.9$, and $16.05 \pm 4.1 \mu \mathrm{g} \mathrm{g}^{-1}$ of $\mathrm{Hg}$ concentration, respectively, with no significant difference among groups supplemented with 10 and 50; and 50 and $100 \mathrm{mg} \mathrm{L}^{-1}\left(\mathrm{LSD}=12.93 \mu \mathrm{g} \mathrm{g}^{-1}\right)$. Stems showed concentrations corresponding to $8.93 \pm 2.1,17.51 \pm 4.9$, and $24.61 \pm 6.7 \mu \mathrm{g} \mathrm{g}^{-1}$, respectively, with no significant difference among groups supplemented with 10 and 50; and 50 and 100 mg L ${ }^{-1}(L S D=19.21)$. Statistical results obtained from ANOVA (Table 1) show significant variation $(\mathrm{CI}=95 \%)$ of $\mathrm{Hg}$ concentration in roots, stems, and leaves regard different $\mathrm{Hg}$ concentrations in irrigation water.

Higher $\mathrm{Hg}$ concentrations in roots can be explained considering that the defense mechanism of plants against heavy metals is to hold metals in the root to avoid damage to aerial organs. ${ }^{12}$ In addition it has been suggested that it is possible that plants are able to contribute to the release of $\mathrm{Hg}$ to the air by taking up $\mathrm{Hg}$ from the soil, translocating it to the leaves and releasing it via the stomata. ${ }^{27}$

3.2. Determinations of $\mathrm{Hg}_{\text {org }}$ and $\mathrm{Hg}_{\text {inorg }}$. Extraction of $\mathrm{Hg}_{\text {org }}$ and $\mathrm{Hg}_{\text {inorg }}$ fractions employing the described procedure in section 2.1.2 was assessed with recoveries between 44 and $60 \%$ compared with complete digestion. The fractions were evaluated employing $\mathrm{SnCl}_{2}$ as reducing reagent to determine only $\mathrm{Hg}_{\text {inorg }}\left(\right.$ as $\mathrm{Hg}^{2+}$ ), and by the introduction of $\mathrm{NaBH}_{4}$, $\mathrm{K}_{2} \mathrm{~S}_{2} \mathrm{O}_{8}$, and $\mathrm{UV}$ radiation into the FI system, the decomposition of both fractions, $\mathrm{Hg}_{\text {org }}$ and $\mathrm{Hg}_{\text {inorg }}$ was achieved. $\mathrm{Hg}_{\text {org }}$ was calculated by difference.

$\mathrm{Hg}$ distribution into $\mathrm{Hg}_{\text {inorg }}$ and $\mathrm{Hg}_{\text {org }}$ fractions can be observed in Figure 2 and Table 2 for each study group and 
Table 1. One way ANOVA for the Effect of $\mathrm{Hg}$ Concentration in Irrigation Water on $\mathrm{Hg}$ Uptake by Vitis vinifera ${ }^{a}$

\begin{tabular}{|c|c|c|c|c|c|c|c|c|c|}
\hline \multirow[t]{2}{*}{ effect } & \multicolumn{3}{|c|}{ roots } & \multicolumn{2}{|c|}{ stems } & \multirow[b]{2}{*}{$p$} & \multicolumn{3}{|c|}{ leaves } \\
\hline & $\mathrm{dF}$ & F & $p$ & $\mathrm{dF}$ & $\mathrm{F}$ & & $\mathrm{dF}$ & $\mathrm{F}$ & $p$ \\
\hline $\mathrm{Hg}$ concentration in irrigation water & 6 & $30.91^{b}$ & 0.0006 & 6 & $7.56^{b}$ & 0.022 & 6 & $14.12^{b}$ & 0.005 \\
\hline
\end{tabular}

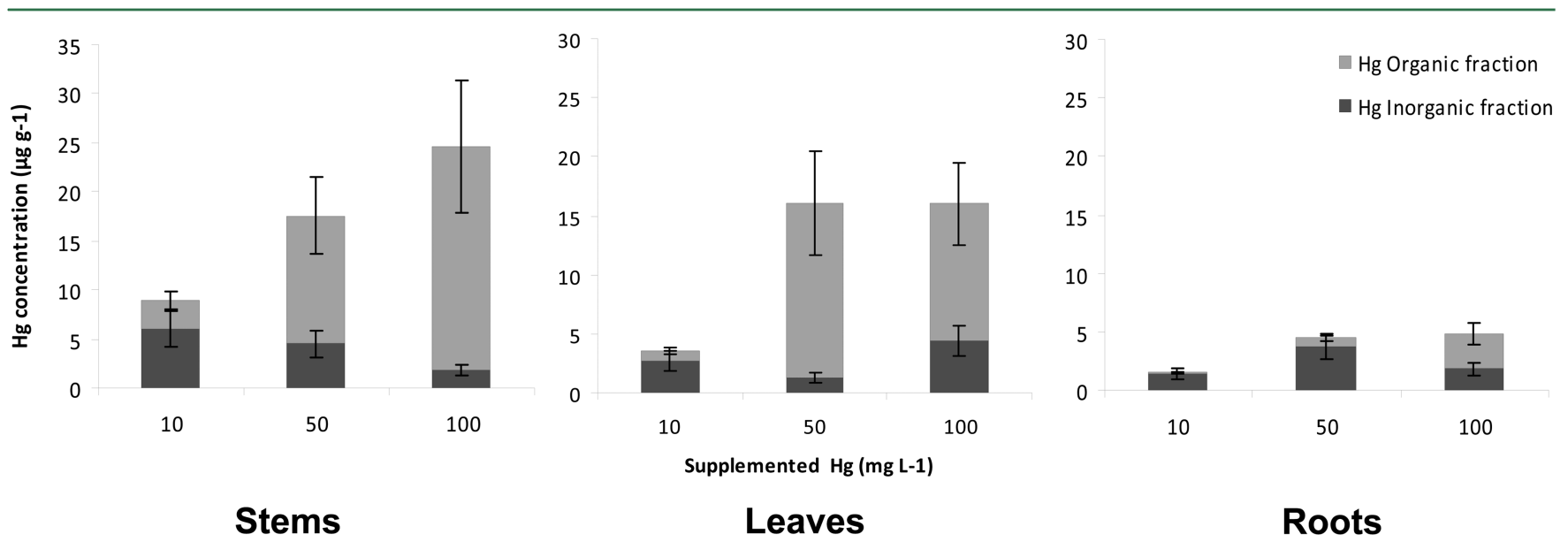

Figure 2. $\mathrm{Hg}_{\text {org }}$ and $\mathrm{Hg}_{\text {inorg }}$ concentration into the different vine compartments evaluated for 10, 50, and $100 \mathrm{mg} \mathrm{L}^{-1}$ of $\mathrm{Hg}^{2+}$ supplementation. Results are expressed as the mean \pm standard deviation of three plants.

Table 2. $\mathrm{Hg}_{\text {org }}$ and $\mathrm{Hg}_{\text {inorg }}$ Distribution in the Different Vine Organs

\begin{tabular}{|c|c|c|c|c|c|c|c|c|}
\hline \multirow[b]{3}{*}{ supplemented $\mathrm{Hg}^{2+}\left(\mathrm{mg} \mathrm{L}^{-1}\right)$} & \multicolumn{8}{|c|}{$\mathrm{Hg}_{\text {org }}$ and $\mathrm{Hg}_{\text {inorg }}$ distribution $\left(\mu \mathrm{g} \mathrm{g}^{-1}\right)^{a}$} \\
\hline & \multicolumn{2}{|c|}{ roots } & \multicolumn{2}{|c|}{ stems } & \multicolumn{2}{|c|}{ leaves } & \multicolumn{2}{|c|}{ total } \\
\hline & $\mathrm{Hg}_{\text {org }}$ & $\mathrm{Hg}_{\text {inorg }}$ & $\mathrm{Hg}_{\text {org }}$ & $\mathrm{Hg}_{\text {inorg }}$ & $\mathrm{Hg}_{\text {org }}$ & $\mathrm{Hg}_{\text {inorg }}$ & $\mathrm{Hg}_{\text {org }}$ & $\mathrm{Hg}_{\text {inorg }}$ \\
\hline 10 & $0.06 \pm 0.02$ & $1.57 \pm 0.3$ & $2.84 \pm 0.7$ & $5.42 \pm 0.9$ & $0.82 \pm 0.3$ & $2.4 \pm 0.15$ & $3.67 \pm 0.6$ & $9.28 \pm 1.9$ \\
\hline 50 & $0.71 \pm 0.1$ & $3.61 \pm 0.9$ & $13.05 \pm 3.0$ & $4.75 \pm 1.3$ & $14.73 \pm 3.6$ & $1.86 \pm 0.12$ & $28.49 \pm 6.3$ & $11.7 \pm 2.5$ \\
\hline 100 & $3.03 \pm 1.2$ & $2.01 \pm 0.2$ & $22.76 \pm 4.2$ & $1.93 \pm 0.2$ & $11.64 \pm 3.5$ & $5.17 \pm 0.6$ & $37.42 \pm 9.2$ & $10.89 \pm 2.4$ \\
\hline
\end{tabular}

${ }^{a}$ Results are expressed as the mean \pm standard deviation of 3 plants.

plant organs. Different distribution of $\mathrm{Hg}_{\text {org }}$ was observed for the studied groups. The highest $\mathrm{Hg}_{\text {org }}$ concentration corresponds to the group supplemented with $100 \mathrm{mg} \mathrm{L}^{-1}$ and $50 \mathrm{mg}$ $\mathrm{L}^{-1}$ of $\mathrm{Hg}^{2+}$, with $37.42 \pm 9.2 \mu \mathrm{g} \mathrm{g}^{-1}$ and $28.49 \pm 6.3$, respectively, (no significant difference, LSD $=25.05$ ), followed by the group supplemented with $10 \mathrm{mg} \mathrm{L}^{-1}, 3.67 \pm 0.6 \mu \mathrm{g} \mathrm{g}^{-1}$. As it can be observed, the presence of $\mathrm{Hg}_{\text {org }}$ in vine plants is not proportional to the quantities of supplemented $\mathrm{Hg}$ into irrigation waters. $\mathrm{Hg}_{\text {org }}$ distribution within the different organs of vines showed that stems possess the highest $\mathrm{Hg}_{\text {org }}$ concentration with $22.76 \pm 4.2 \mu \mathrm{g} \mathrm{g}^{-1}$ corresponding to the group supplemented with $100 \mathrm{mg} \mathrm{L}^{-1}$. The highest $\mathrm{Hg}_{\text {org }}$ found in stems suggests that one response of vines to $\mathrm{Hg}$ stress is the active translocation of this metal from roots to leaves through stems. Toxic metals taken up into the root reaches the xylem for upward transport. ${ }^{28}$ Roots on the other hand showed the lowest $\mathrm{Hg}_{\text {org }}$ content with $0.06 \pm 0.02 \mu \mathrm{g} \mathrm{g}^{-1}$ for the group supplemented with $10 \mathrm{mg} \mathrm{L}^{-1}$. These $\mathrm{Hg}_{\text {org }}$ concentration values are correlated with $\mathrm{Hg}$ translocation and storage process from nonaerial to aerial organs of vines due to the lowest $\mathrm{Hg}_{\text {org }}$ found in roots compared with higher $\mathrm{Hg}_{\text {org }}$ levels found in stems and leaves.

$\mathrm{Hg}_{\text {inorg }}$ and $\mathrm{Hg}_{\text {org }}$ concentration into the different organs of vine plants, nonaerial and aerial, can be observed in Table 2 and Figure 2. Vine plants supplemented with $10 \mathrm{mg} \mathrm{L}^{-1}$ of $\mathrm{Hg}^{2+}$ showed a lower $\mathrm{Hg}_{\text {org }}$ concentrations in the nonaerial and aerial organs of the plant compared with other studied groups. On the other hand, when $\mathrm{Hg}$ stress is heavier, the presence of $\mathrm{Hg}_{\text {org }}$ is elevated in stems and leaves, between 72.47 and $92.48 \%$ (considering the sum of $\mathrm{Hg}_{\text {inorg }}$ and $\mathrm{Hg}_{\text {org }}$ equal to $100 \%$ ). These observations are explained by Cobbet and Goldsbrough $^{29}$ who stablished that $\mathrm{Hg}_{\text {org }}$ complexes are able to induce the production of $\mathrm{Hg}$ ligands in a positive feedback system. The two best-characterized heavy metal-binding ligands in plant cells are the phytochelatins (PCs) and metallothioneins (MTs). ${ }^{29}$ In vivo studies have shown that PC synthesis can be induced by a range of metal ions in both intact plants and plant cell cultures. ${ }^{30}$ PCs and MTs are peptides and proteins rich in sulfur residues able to form thiolate bonds with $\mathrm{Hg}^{31}$ being responsible of sequestering $\mathrm{Hg}$ to avoid toxic effects.

3.3. Size Exclusion Chromatography Analysis. As described previously, $\mathrm{Hg}$ is present in stems and leaves of vines supplemented with $100 \mathrm{mg} \mathrm{Hg} \mathrm{L}^{-1}$, mainly as $\mathrm{Hg}_{\text {org. }}$. SEC analysis was applied to determine $\mathrm{Hg}$ distribution within this fraction. $S$ was determined simultaneously in order to investigate the presence of $\mathrm{Hg}-\mathrm{S}$ complexes inferring the presence of peptides and proteins ${ }^{32}$ like PCs or MTs for instance. The employed SEC column separates in a wide range from 10 to $700 \mathrm{kDa}$. Since the extraction was performed with a TRIS-SDS solution, water-soluble $\mathrm{Hg}$ compounds such as proteins, polysaccharides, amino acids, polypeptides, and $\mathrm{Hg}$ protein complexes were extracted with TRIS. Water-insoluble $\mathrm{Hg}$ protein complexes were extracted with SDS (an anionic tensoactive solution). ${ }^{33} \mathrm{Hg}$ extraction efficiency compared with 

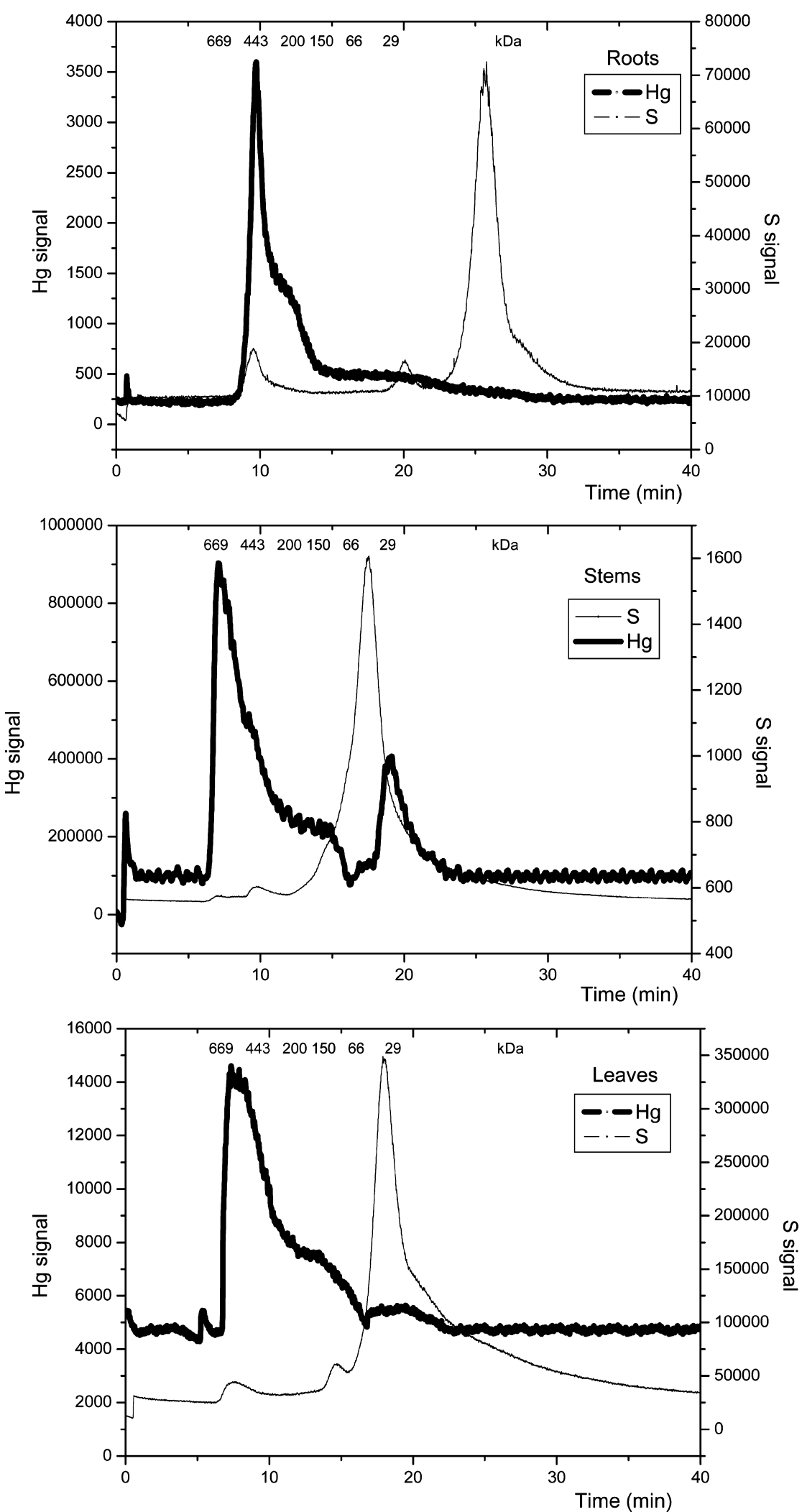

Figure 3. SEC-ICP MS chromatograms of plant compartments supplemented with $100 \mathrm{mg} \mathrm{L}^{-1}$. Molecular weight markers can be observed in the upper side of graphics.

total $\mathrm{Hg}$ determinations was $0.47,0.12$, and $2.8 \%$ in roots, stems, and leaves, respectively. Formation of $\mathrm{Hg}-\mathrm{S}$ complexes was confirmed by the injection of a 2-mercaptoethanol-Hg solution.
Figure 3 shows SEC chromatograms of roots, leaves, and stems extracts supplemented with $100 \mathrm{mg} \mathrm{L}^{-1}$ of $\mathrm{Hg}^{2+}$. The studied plant organs show that in the $\mathrm{Hg}_{\text {org }}$ fraction, this metal is bond mainly to high molecular weight fractions from 669 to 
$443 \mathrm{kDa}$. Since the molecular weight is too high, protein binding in this range is disregarded. Fractions containing $S$ also appear at this high molecular weight range, but at lower concentrations compared with medium and low molecular weight fractions, $\sim 66 \mathrm{kDa}$ and lower. $\mathrm{Hg}-\mathrm{S}$ complexes are also present at these levels suggesting a possible $\mathrm{Hg}$ binding to proteins or peptides in stems. In roots and leaves $\mathrm{Hg}$ is present only in high molecular weight fractions. $\mathrm{Hg}$ is not associated to $S$ in medium and low molecular weight fractions despite $S$ presence.

$\mathrm{Hg}$ concentrations in the extracts were of $0.018 \pm 0.003$, $0.041 \pm 0.001$, and $0.38 \pm 0.07 \mu \mathrm{g} \mathrm{g}^{-1}$ in roots, stems, and leaves, respectively of plants supplemented with $100 \mathrm{mg} \mathrm{L}^{-1}$ of $\mathrm{Hg}^{2+}$. This tendency is coincident with $\mathrm{Hg}_{\text {org }}$ concentration, were higher $\mathrm{Hg}_{\text {org }}$ is observed in stems and leaves.

3.4. Ion Pair Chromatography Analysis. As stated in the previous section, high levels of $\mathrm{Hg}_{\text {org }}$ into stems and leaves in vines for the studied groups were found. In an attempt to elucidate the composition of $\mathrm{Hg}_{\text {org }}$, the presence of $\mathrm{Hg}$ species was evaluated through IPC with UV-CV-AFS system as $\mathrm{Hg}$ detection. The different $\mathrm{Hg}$ species analyzed were $\mathrm{Hg}^{2+}$, $\mathrm{MeHg}^{+}, \mathrm{Me}_{2} \mathrm{Hg}$, and $\mathrm{PhHg}^{+}$, and they can be observed in Figure 4. Analysis of these species becomes relevant
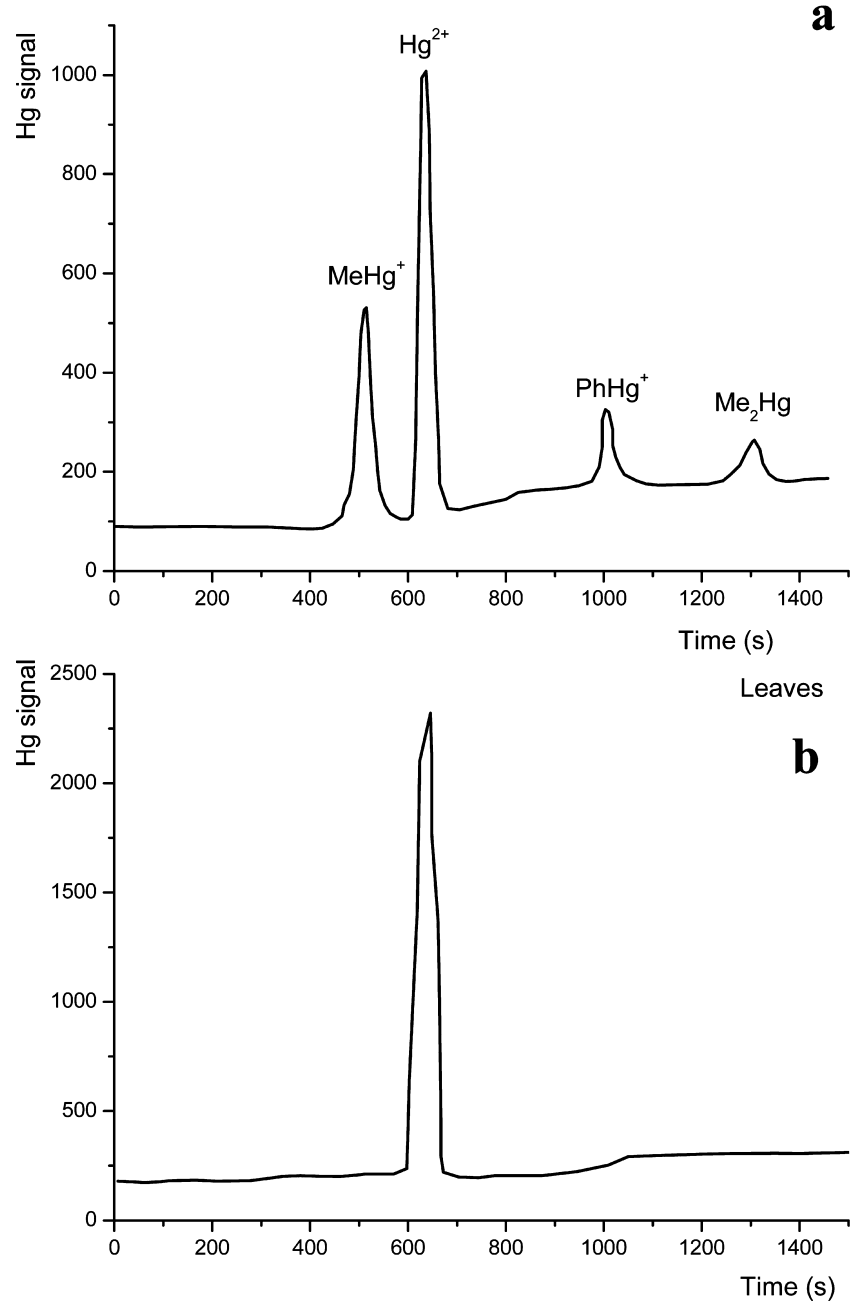

Figure 4. IPC-UV-CV-AFS chromatograms. (a) Standards injection of $50 \mu \mathrm{g} \mathrm{L}^{-1}$ of $\mathrm{MeHg}^{+}(446 \mathrm{~s}), \mathrm{Hg}^{2+}$ (551 s), $\mathrm{PhHg}^{+}$ (875 s), $\mathrm{Me}_{2} \mathrm{Hg}$ (1138 s). b) Sample injection (leaves), $\mathrm{Hg}^{2+}$ (551 s), supplemented with $100 \mathrm{mg} \mathrm{L}^{-1} \mathrm{Hg}$. considering their high toxicity and bioavailability level, even higher than $\mathrm{Hg}^{2+}$. The only $\mathrm{Hg}$ specie found was $\mathrm{Hg}^{2+}$. As an example the only chromatogram showed is the corresponding to leaves extract analysis. $\mathrm{Hg}$ species analysis confirms that vine plants do not methylate $\mathrm{Hg}^{2+}$. Meng et $\mathrm{al}^{23}$ observations established that $\mathrm{MeHg}^{+}, \mathrm{Me}_{2} \mathrm{Hg}$, or $\mathrm{PhHg}^{+}$are exogenous to plants, they do not synthesize them. Since the only supplemented $\mathrm{Hg}$ specie was $\mathrm{Hg}^{2+}$, unless $\mathrm{MeHg}^{+}, \mathrm{Me}_{2} \mathrm{Hg}$ or $\mathrm{PhHg}^{+}$were added into the irrigation water, or were present in soil due to other mechanisms (like methylation by microorganisms for instance), they will not be present in vine plants organs. This was confirmed by the analysis of a possible $\mathrm{Hg}$ methylation in soil after $\mathrm{Hg}$ supplementation. The only $\mathrm{Hg}$ specie found in soil available to root after the extraction procedure at the harvesting time was $\mathrm{Hg}^{2+}$. Concentrations of $\mathrm{Hg}^{2+}$ found were ranging from 0.21 to $0.49 \mu \mathrm{g} \mathrm{g}^{-1}$, similar to those found by Maserati and Ferrara ${ }^{34}$ in soils near a chloralkali complex, showing a clear contaminated soil after $\mathrm{Hg}$ supplementation through irrigation water, reaching in a greenhouse, field conditions. Despite these results, the uptake of $\mathrm{MeHg}^{+}$or other organic forms of $\mathrm{Hg}$ by vine plants could not be confirmed by this study. Beyond this statement, it is clear that $\mathrm{Hg}$ methylation did not occur in soil or plants at least one week after supplementation.

3.5. Evaluation of Uptake Parameters. In order to evaluate the $\mathrm{Hg}$ uptake capacity of vine plants and $\mathrm{Hg}$ transfer up to aerial parts of the plant, in Table 3 are depicted the bioaccumulation factor (BAF) (vegetation/soil) and transfer (aerial parts/fine roots) coefficients in Vitis vinifera L. $c v$. Malbec.

Table 3. Accumulation (Vegetation/Soil) Ratios and Transfer (Aerial Parts/Fine Roots) Coefficients in Vine Plants

$\begin{array}{cccc}\begin{array}{c}\text { supplemented } \\ \mathrm{Hg}^{2+}\left(\mathrm{mg} \mathrm{L}^{-1}\right)\end{array} & \begin{array}{c}\text { bioavailable } \mathrm{Hg} \\ \left(\mu \mathrm{g} \mathrm{g}^{-1}\right)\end{array} & \begin{array}{c}\text { bioaccumulation } \\ \text { Factor }(\mathrm{BAF})\end{array} & \begin{array}{c}\text { transfer } \\ \text { coefficient }^{c a}\end{array} \\ 10 & 0.011 \pm 0.001 & 1509.9 \pm 270.7 & 0.07 \\ 50 & 0.043 \pm 0.005 & 757.4 \pm 128.9 & 0.10 \\ 100 & 0.08 \pm 0.006 & 572.2 \pm 94.6 & 0.08\end{array}$

${ }^{a}$ Results are expressed as the mean \pm standard deviation of three plants. ${ }^{b} \mathrm{BAF}=\mathrm{Hg}$ concentration in root/bioavailable $\mathrm{Hg}$ in soil). ${ }^{c}$ Transfer coefficient $=\mathrm{Hg}$ in aerial compartments $/ \mathrm{Hg}$ in nonaerial compartments.

BAF provide comparison between different types of vegetation and soils (element concentration in vegetation root/available $\mathrm{Hg}$ concentration in soil). ${ }^{9}$ In addition, since there is a lack of data for Vitis vinifera L., therefore, BAF could provide comparison between different types of vegetation and soils and provide a better understanding of the relationship between available $\mathrm{Hg}$ concentration in soil and $\mathrm{Hg}$ concentration in vegetation. ${ }^{19}$ As shown in Table 3, BAF values correspond to $1509.9 \pm 270.7,757.4 \pm 128.9$, and $572.2 \pm 94.6$ for groups supplemented with 10, 50, and $100 \mathrm{mg} \mathrm{L}^{-1}$, respectively. BAFs are similar, despite being different species, to those values obtained by Moreno-Jiménez et al. ${ }^{36}$ for $\mathrm{Hg}$ uptake by Rumex induratus and Marrubium vulgare, employing the same BAF formula and $\mathrm{Hg}$ administration. BAFs for $\mathrm{Hg}$ uptake have not been reported for Vitis vinifera L. before.

Since trace elements accumulated in roots could be translocated to other plant organs ${ }^{12}$ the transfer coefficient of the different vine groups are shown in Table 3. The determined 
values correspond to $0.74 \pm 0.17,1.02 \pm 0.22$, and $0.89 \pm 0.17$ for groups supplemented 10,50, and 100 ug $\mathrm{L}^{-1}$ of $\mathrm{Hg}$, respectively. The similarity between these transfer coefficients can be explained considering that the studied plants are clones. These transfer coefficients turn Vitis vinifera into an indicator for $\mathrm{Hg}$ contamination in soils according to Baker classification ${ }^{35}$ (accumulators, TC > 1.5; indicators, TC from 0.5 to 1.5 , and excluders, $\mathrm{TC}<0.1)$

\section{ENVIRONMENTAL RELEVANCE}

Irrigation waters can be contaminated from different sources like industrial effluents, wastewaters, and geological processes. Since $\mathrm{Hg}$ can be released from natural sources and from different industries like manufacturing of caustic soda and chlorine, this metal can reach aqueducts or irrigation channels. It was shown that vines uptake $\mathrm{Hg}$ proportionally to a shortterm supplementation. Once absorbed, $\mathrm{Hg}$ distributes in roots, stems, and leaves, mostly as organic fraction of 669-443 and $\sim 66 \mathrm{kDa}$ in stems. Within this last fraction $\mathrm{Hg}$ is associated to sulfur, indicating protein or peptide binding. Once $\mathrm{Hg}$ is absorbed it was demonstrated that it is not metabolized into more hazardous species like $\mathrm{MeHg}^{+}, \mathrm{Me}_{2} \mathrm{Hg}$, or $\mathrm{PhHg}^{+}$, under these experimental conditions, with a $\mathrm{Hg}$ short-term exposure.

\section{ASSOCIATED CONTENT}

\section{S Supporting Information}

Additional information on reagents and instrumentation, inductively coupled plasma mass spectrometry (ICP MS), atomic fluorescence spectrometry (AFS) and high performance liquid chromatography (HPLC) is available. This material is available free of charge via the Internet at http://pubs.acs.org.

\section{AUTHOR INFORMATION}

\section{Corresponding Author}

*Phone: +54-266-4425385; fax: +54-2664-430224; e-mail: ldm@unsl.edu.ar.

\section{Notes}

The authors declare no competing financial interest.

\section{ACKNOWLEDGMENTS}

This work was supported by Consejo Nacional de Investigaciones Cientificas yTécnicas (CONICET), Agencia Nacional de Promoción Científica y Tecnológica (FONCYT) (PICTBID), Universidad Nacional de Cuyo (Argentina), Universidad Nacional de San Luis (Argentina), and Instituto Nacional de Técnicas Agropecuarias (INTA), Estación Experimental Mendoza.

\section{REFERENCES}

(1) Fergusson, J. E. The Heavy Elements: Chemistry, Environmental Impact and Health Effects; Pergamon Press: Oxford, 1990.

(2) Marczenko, Z.; Lobinski, R. Spectrochemical Trace Analysis for Metals and Metalloids; Elsevier: Amsterdam, 1996.

(3) Craig, P. J. Organometallic Compounds in the Environment; Longman: London, 1986.

(4) Hanisch, C. Where is mercury deposition coming from? Uncertainties about the roles of different natural and synthetic sources are fueling the debate on how to regulate emissions. Environ. Sci. Technol. 1998, 32 (7), 176A-179A.

(5) Holsapple, J. The mercury cycle and fish in the adirondack lakes. Environ. Sci. Technol. 1994, 28 (3), 136A-143A.
(6) Garcia, J. S.; De Magalhães, C. S.; Arruda, M. A. Z. Trends in metal-binding and metalloprotein analysis. Talanta 2006, 69 (1), 115.

(7) Gopal, R.; Rizvi, A. H. Excess lead alters growth, metabolism and translocation of certain nutrients in radish. Chemosphere 2008, 70 (9), $1539-1544$.

(8) Peralta-Videa, J. R.; Lopez, M. L.; Narayan, M.; Saupe, G.; Gardea-Torresdey, J. The biochemistry of environmental heavy metal uptake by plants: Implications for the food chain. Int. J. Biochem. Cell Biol. 2009, 41 (8-9), 1665-1677.

(9) Jung, M. C.; Thornton, I. Heavy metal contamination of soils and plants in the vicinity of a lead-zinc mine, Korea. App. Geochem. 1996, 11 (1-2), 53-59.

(10) Chopin, E. I. B.; Alloway, B. J. Distribution and mobility of trace elements in soils and vegetation around the mining and smelting areas of Tharsis, Ríotinto and Huelva, Iberian Pyrite Belt, SW Spain. Water, Air, Soil Pollut. 2007, 182 (1-4), 245-261.

(11) Lee, C. G.; Chon, H. T.; Jung, M. C. Heavy metal contamination in the vicinity of the Daduk $\mathrm{Au}-\mathrm{Ag}-\mathrm{Pb}-\mathrm{Zn}$ mine in Korea. App. Geochem. 2001, 16 (11-12), 1377-1386.

(12) Pendias, H.; Kabata-Pendias, A. Trace Elements in Soils and Plants; CRC Press: Boca Raton, 2001.

(13) Komárek, M.; Čadková, E.; Chrastný, V.; Bordas, F.; Bollinger, J. C. Contamination of vineyard soils with fungicides: A review of environmental and toxicological aspects. Environ. Int. 2010, 36 (1), 138-151.

(14) Volpe, M. G.; La Cara, F.; Volpe, F.; De Mattia, A.; Serino, V.; Petitto, F.; Zavalloni, C.; Limone, F.; Pellecchia, R.; De Prisco, P. P.; Di Stasio, M. Heavy metal uptake in the enological food chain. Food Chem. 2009, 117 (3), 553-560.

(15) Fabani, M. P.; Toro, M. E.; Vázquez, F.; Díaz, M. P.; Wunderlin, D. A. Differential absorption of metals from soil to diverse vine varieties from the valley of tulum (Argentina): Consequences to evaluate wine provenance. J. Agr. Food Chem. 2009, 57 (16), 74097416.

(16) Saleem-Saif, M.; Midrar-Ul-Haq; Memon, K. S. Heavy metals contamination through industrial effluent to irrigation water and soil in Korangi Area of Karachi (Pakistan). Int. J. Agric. Biol. 2005, 7, 646648.

(17) Wu, G. H.; Cao, S. S. Mercury and cadmium contamination of irrigation water, sediment, soil and shallow groundwater in a wastewater-irrigated field in Tianjin, China. Bull. Environ. Contam. Toxicol. 2010, 84 (3), 336-341.

(18) Domagalski, J. L.; Alpers, C. N.; Slotton, D. G.; Suchanek, T. H.; Ayers, S. M. Mercury and methylmercury concentrations and loads in the Cache Creek watershed, California. Sci. Total Environ. 2004, 327 (1-3), 215-237.

(19) Chopin, E. I. B.; Marin, B.; Mkoungafoko, R.; Rigaux, A.; Hopgood, M. J.; Delannoy, E.; Cancès, B.; Laurain, M. Factors affecting distribution and mobility of trace elements $(\mathrm{Cu}, \mathrm{Pb}, \mathrm{Zn})$ in a perennial grapevine (Vitis vinifera L.) in the Champagne region of France. Environ. Pollut. 2008, 156 (3), 1092-1098.

(20) Leita, L.; Mondini, C.; De Nobili, M.; Simoni, A.; Sequi, P. Heavy metal content in xylem sap (Vitis vinifera) from mining and smelting areas. Environ. Monit. Assess. 1998, 50 (2), 189-200.

(21) Todic, S.; Beslic, Z.; Lakic, N.; Tesic, D. Lead, mercury, and nickel in grapevine, Vitis vinifera L., in polluted and nonpolluted regions. Bull. Environ. Contam. Toxicol. 2006, 77 (5), 665-670.

(22) Afton, S. E.; Catron, B.; Caruso, J. A. Elucidating the selenium and arsenic metabolic pathways following exposure to the nonhyperaccumulating Chlorophytum comosum, spider plant. J. Exp. Bot. 2009, 60 (4), 1289-1297.

(23) Meng, B.; Feng, X.; Qiu, G.; Cai, Y.; Wang, D.; Li, P.; Shang, L.; Sommar, J. Distribution patterns of inorganic mercury and methylmercury in tissues of rice (Oryza sativa L.) plants and possible bioaccumulation pathways. J. Agric. Food Chem. 2010, 58 (8), 49514958.

(24) Cattani, I.; Spalla, S.; Beone, G. M.; Del Re, A. A. M.; Boccelli, R.; Trevisan, M. Characterization of mercury species in soils by HPLC- 
ICP-MS and measurement of fraction removed by diffusive gradient in thin films. Talanta. 2008, 74 (5), 1520-1526.

(25) Kápolna, E.; Shah, M.; Caruso, J. A.; Fodor, P. Selenium speciation studies in Se-enriched chives (Allium schoenoprasum) by HPLC-ICP-MS. Food Chem. 2007, 101 (4), 1398-1406.

(26) Pacheco, P. H.; Spisso, A.; Cerutti, S.; Smichowski, P.; Martinez, L. D. Non-chromatographic screening method for the determination of mercury species. Application to the monitoring of mercury levels in Antarctic samples. Talanta. 2010, 82 (4), 1505-1510.

(27) Greger, M.; Wang, Y.; Neuschütz, C. Absence of $\mathrm{Hg}$ transpiration by shoot after $\mathrm{Hg}$ uptake by roots of six terrestrial plant species. Environ. Pollut. 2005, 134 (2), 201-208.

(28) Clemens, S.; Palmgren, M. G.; Krämer, U. A long way ahead: Understanding and engineering plant metal accumulation. Trends Plant Sci. 2002, 7 (7), 309-315.

(29) Cobbett, C.; Goldsbrough, P. Phytochelatins and metallothioneins: Roles in heavy metal detoxification and homeostasis. Annu. Rev. Plant Biol. 2002, 53 (1), 159-82.

(30) Rauser, W. E. Phytochelatins and related peptides. Structure, biosynthesis, and function. Plant Physiol. 1995, 109 (4), 1141-1149.

(31) Krupp, E. M.; Milne, B. F.; Mestrot, A.; Meharg, A. A.; Feldmann, J. Investigation into mercury bound to biothiols: Structural identification using ESI-ion-trap MS and introduction of a method for their HPLC separation with simultaneous detection by ICP-MS and ESI-MS. Anal. Bioanal. Chem. 2008, 390 (7), 1753-1764.

(32) Bettmer, J.; Montes Bayón, M.; Ruiz Encinar, J.; Fernández Sánchez, M. L.; Fernández de la Campa, M. d. R.; Sanz Medel, A. The emerging role of ICP-MS in proteomic analysis. J. Proteomics 2009, 72 (6), 989-1005.

(33) Mounicou, S.; Shah, M.; Meija, J.; Caruso, J. A.; Vonderheide, A. P.; Shann, J. Localization and speciation of selenium and mercury in Brassica juncea-Implications for Se-Hg antagonism. J. Anal. Atom. Spectrom. 2006, 21 (4), 404-412.

(34) Maserti, B. E.; Ferrara, R. Mercury in plants, soil and atmosphere near a chlor-alkali complex. Water, Air, Soil Pollut. 1991, $56,15-20$.

(35) Baker, A. J. M. Accumulators and excluders-Strategies in the response of plants to heavy-metals. J. Plant. Nutr. 1981, 3, 643-654.

(36) Moreno-Jiménez, E.; Gamarra, R.; Carpena-Ruiz, R. O.; Millán, R.; Peñalosa, J. M.; Esteban, E. Mercury bioaccumulation and phytotoxicity in two wild plant species of Almadén area. Chemosphere. 2006, 63, 1969-1973. 